\title{
SHORTCOMINGS IN THE HISTORIOGRAPHY OF TRANSLATION*
}

\author{
Anthony Pym
}

Published in Babel 38/4 (1992), 221-235. A shorter version was published as "Complaint Concerning the Lack of History in Translation Histories", Livius. Revista de Estudios de Traducción 1 (1992), 1-11.

\section{Résumé}

A l'heure où les relations internationales subissent de profonds changements, l'historiographie de la traduction réveille un nouvel intérêt. Or, les méthodes qu'elle utilise sont-elles à la hauteur des circonstances? Nous voudrions, dans cet article, formuler une hypothèse sur l'effet historique des traductions, non pas pour la justifier empiriquement mais afin de voir comment certaines approches contemporaines pourraient la vérifier. Nous constatons que, du point de vue de notre hypothèse, ces approches comportent sept inconvénients méthodologiques: a) l'accumulation archéologique de données qui ne répondent à aucune problématique explicite, b) la dépendance générale du matériau anecdotique, c) la périodisation indiscriminée, d) les traductions vues comme expressions plutôt que comme facteurs de changements historiques, e) le privilège axiomatique accordé aux cultures cibles, f) des hypothèses infalsifiables, g) peu d'espace systémique pour l'interculturalité du traducteur.

Rapid and radical changes in international relations have helped make interculturality a privileged object of historical research. At the same time, new emphasis has been placed on the history of translation as an important intercultural activity about which there is still much to learn. But as attention is turned to the names of past translators and long lists of past translations, few researchers have clear ideas about exactly what they hope to find and how they hope to find it. The historiography of translation thus remains mostly impressionistic, with little attention to the kind of actively scientific basis that might be gained through the testing of falsifiable hypotheses.

In order to formulate a general complaint about this situation - in order to say how I think translation history should be written -, I shall present just one falsifiable hypothesis and then assess how certain fairly well-known historical approaches might go about testing or avoiding it. My comments will first deal with three representative passages concerning nineteenth-century translation practices in Europe, then an important system-based study of the role of translation within French Romanticism, and finally three brief examples of what I consider to be more general conceptual 
shortcomings. The nature of the enterprise means that I will be focusing on only the weak points or blind spots of otherwise very good historians, all of whom merit far more respect than can be accorded here.

And so to a rather disrespectful hypothesis.

\section{Incompatibilities of the prose-effect hypothesis}

It is possible that prose translations of verse actively assisted in the progressive prosification of European lyrical expression in the nineteenth century. This "proseeffect hypothesis" implies that prose translations did not merely reflect developments in the prose poem, vers libre and poetic prose, but were causally related to these developments. As such, I consider the hypothesis to be properly historical in that it identifies a change process, it constructs an explanatory narrative, it is potentially falsifiable on the basis of empirical evidence, and it addresses a contemporary problematic (it is pertinent to the position of any translator faced with a choice between verse and prose as target forms). My prime concern here is not with defending the hypothesis as such, nor with elaborating its historicity, but with explaining its apparent incompatibility with several widely held beliefs according to which nineteenth-century translating was predominantly "literalist", "mimetic" or oriented towards "formal equivalence". According to these latter beliefs, nineteenth-century translators should massively have rendered verse as verse and the prosification of genre systems should only have been affected by the transfer of existing forms. My hypothesis would then be false. But one should never give up so easily. The hypothesis is, after all, of some importance. Although certain modes of prosification can be seen as having been assisted by mimetic translation practices - for example, the transfer of blank verse from English into German and Dutch, or Laforgue's formally mimetic translation of Whitman as a major step towards the vers libre -, the prose-effect hypothesis insists that some translations were more than mere repetitions of foreign forms; it insists that some prose translations actively contributed to a process of historical change; it concerns translation as something more than passive representation. Either the hypothesis is wrong or trivial, or there is something fundamentally wrong or trivialising in certain approaches to translation history. Rather than give up without a fight, I shall defend the latter opinion.

\section{Historiography is neither archeology nor criticism}

Most of what are commonly accepted as texts on the history of translation in fact belong to either archeology or criticism rather, and not strictly to historiography. It is perhaps useful to propose a few basic definitions: 
Archeology addresses the questions "who?", "where?", "when?" and "what? (which text?)". As such, it provides the data needed to defend or attack historical hypotheses.

Criticism explores intertextual relations in order to address the question "how?" and to project the values needed for an ethical or aesthetic appreciation of historical hypotheses.

Although these two activities roughly correspond to what the Göttingen group terms external and internal translation history (Frank 1989), I believe that neither can become properly historical until they project substantial responses to the questions "why this text? (why not another?)", "why in this way? (why not in another)" and "with what actual effect?". Archeological research can reveal circumstantial motives obliquely pertinent to such questions (e.g. "Manet urged Mallarmé to translate Poe in order to fleece an American publisher"); criticism may provide further theoretical insights (e.g. "Baudelaire translated Poe in order to create a doppelgänger"); but neither archeology nor criticism is able to formulate hypotheses or problematics strictly pertinent to dynamics of change; neither archeology nor criticism is able to justify and describe the finality of their potentially unlimited gathering of "fascinating" data or random recovery of "forgotten" texts. In an age of excessive information and limited orientation, it is simply dangerous to assume that an incipient discipline must accumulate data before it can say why it should accumulate data. Good answers depend on good questions, and neither archeology nor criticism are adequately designed to formulate the basic historical question "why?".

\section{Three superficial commentaries}

This problem can be appreciated through the analysis of three textual fragments which, although they have something of archeological and critical interest to say with respect to the prose-effect hypothesis, are unable to say why one kind of translation (verse) might have given way to another (prose). That is, they are historical in all but their capacity to grasp and explain change... which, in history, should be everything.

1. One of Henri Meschonnic's main concerns is the cultural value of literalist translation, particularly of the Old Testament. But his explanations are not limited to Biblical contexts:

\footnotetext{
"Au XIXème siècle, la philosophie du langage de Humboldt (des langues comme visions du monde) autant que la politique des nationalités entrent parmi des composantes romantiques d'un traduire littéral. Hugo juge une traduction bonne quand elle est littérale. [...]
} 
[By contrast] certaines traductions [...] survivent de la fin du siècle dernier ou du début de ce siècle. [...] Les passages dits poétiques sont ceux que la religion et le goût littéraire édulcorent le plus par leur mise en prose: reflet de ce qu'on croyait qu'on pouvait écrire, traduction entièrement idéologique." (1973: 416-417)

In other words, Romantic translators were literalist and rendered verse as verse, whereas early nineteenth-century translators were automatically inferior because they rendered verse as prose.

2. Diametrically opposed to Meschonnic with respect to Bible translation, Eugene Nida has also had cause to reflect on the passage from the nineteenth to the twentieth century:

"The classical revival of the 19th century and the emphasis upon technical accuracy, combined with a spirit of exclusivism among the intelligentsia, conspired to make that century as pedantic in its attitudes toward translation as it was toward many other aspects of learning. [...]

Undoubtedly the principle exponent - for English - of a more literal tendency in translating was Matthew Arnold, who tried to reproduce Homer in English hexameter, and insisted upon close adherence to the form of any original. [...]

The 20th century has witnessed a radical change in translation principles." (1964: 20-21)

Two otherwise opposed researchers thus both agree that the nineteenth century was an age of broadly literalist translation and that the twentieth century has seen the emergence of a less literalist tendency. The only difference is that whereas Meschonnic praises formal fidelity and regrets the prosification of verse forms, Nida believes that "in the translation of poetry one must abandon formal equivalence and strive for dynamic equivalence" (1964: 177). But this conflict strictly concerns criticism, not historiography.

3. James S Holmes rejected such wilfully normative translation histories and instead proposed historical period models based on abstractly generated translation strategies, two of which are "mimetic form" (verse as verse; prose as prose) and "organic form" (the target form being developed from the semantic material of the source text). The historical projection pertinent to our hypothesis reads as follows:

"The mimetic form tends to come to the fore among translators in a period when genre concepts are weak, literary norms are being called into question, and the target 
culture as a whole stands open to outside influences. Hence it is understandable that the mimetic form became the dominant metapoetic form during the nineteenth century. [...]

As fundamentally pessimistic regarding the possibilities of cross-cultural transference as the mimetic approach is fundamentally optimistic, the organic approach has naturally come to the fore in the twentieth century." (1970: 98)

Once again, a literalist nineteenth century is opposed to a non-literalist twentieth century. Although Holmes does at least offer some attempt at historical explanation - an apparently global change from optimism to pessimism - , he in fact goes no further than do Meschonnic or Nida towards explaining any dynamic that might prove or disprove the prose-effect hypothesis. Like Meschonnic and Nida, his approach is not historical in any profound sense that could be of interest to our hypothesis, although it remains of archeological and critical interest.

\section{Evidence should be more than anecdotal}

Even though they have selected very different kinds of evidence as representative of the nineteenth century, the above writers all reach the same basic conclusion. Whether one looks at Humboldt, Arnold or "weak genre concepts", it seems that the nineteenth century must turn out literalist. Or is this a selective vision?

Questions should be asked of the massive epistemological homogeneity assumed by these approaches. Consider, for example, the fact that Wilhelm von Humboldt not only developed the idea that languages manifest different world views, as Meschonnic helpfully reminds us, but also saw prosification as part of the historical development of the human mind (1836: ccxlvii ff.). Moreover, as a translator, he was in fact quite close to the principle of "organic form" that Holmes attributes to the twentieth century (Vega Cernuda 1989: 203). Meschonnic's argument in favour of literalism merely repeats the reductive vision of Humboldt promoted by twentieth-century relativist linguistics, making an historically complex figure little more than an anecdotal footnote. Similarly, and even more blatantly, Nida's reference to Matthew Arnold's literalism conveniently fails to mention that Arnold's principles were formulated in the climate of debate which in 1861 opposed him to Francis Newman. It is not at all clear why Arnold should be more representative of nineteenth-century translation than might be Newman or indeed the general terms of their disagreement as to how to translate Homer.

In these two cases, as in countless others, it has been forgotten that theoretical notions are elaborated in situations of conflict or doubt - nobody writes a theory to state the obvious -, and that conflict and doubt require at least two opposed opinions. It is 
quite unhistorical - not to say undialectic - to suppose that one kind of translation or theory is immediately able to make all others disappear.

Faced with this problem, Holmes at least admits that his models "must be viewed not solely as period forms, but also as literary constants which have continued to exert an influence long after their heyday" (1970: 99). His approach thus accepts that almost everything is possible at almost any time and that historical research can only hope to explain phenomena of statistical concentration. Exceptions must be marginalised, and Holmes does indeed marginalise in order to protect his hypothesis of a literalist nineteenth century: in a footnote he claims that, within the history of literary translation in western European languages, "the French, with their predilection for translations into prose, are something of an exception" (105). The majority rules, and archeology is there to count the votes.

There are several things wrong with this democratic view of historical importance. First, since historical change is commonly motivated by discontent minorities or initially minor technologies, its dynamic tends to escape monolithic periodisations based on numerical majorities. Second, in the field of translation history, archeological data are not passively numerical points but instead form actively directional lines: translations have a habit of going from and to specific times and places. In the case of the nineteenth century, the concrete network formed by these lines is moreover of highly unequal distribution. The latter half of the century reveals a complex transfer pattern increasingly concentrated around Paris, with London as a second major centre up to about 1890 and Berlin-Vienna gaining in importance after that date (Pym 1988). This centralised network should be no surprise for Spanish comparatists, since it is well known that many Slavic, German, Scandinavian and even English-language texts reached Spanish though French. However, the central role played by Paris would perhaps surprise Holmes, who classifies French translation habits as merely exceptional. The truth is that in a world of moving objects, some exceptions can exert considerable influence precisely to the extent that they are exceptionally central.

A basic distinction should thus be made between "intermediary translations", which occupy central positions in that they influence further translational receptions, and "terminal translations", which exert no such influence. The historiography of translation should probably attach more importance to intermediary translations than to the comparative evaluation of different terminal translations, which is more properly the business of translation criticism. A critic might remark, for example, that Poe's "The Raven" was translated into Spanish-American verse by Pérez Bonalde in 1887 and into Russian verse by Bal'mont in 1893. But having remarked this globe-spanning mimetic parallelism, the translation critic cannot construe it as evidence of any globally versifying strategy. After all, the most influential European translations of Poe Baudelaire's mid-century versions - were in prose, and it was in prose that Europeans 
came to see the American as something more than the jingle-jangle rhymer he remains for English readers. The textual parallelisms dealt with by critics are no more likely to guarantee historical importance than are the statistical majorities located by archeology.

\section{Periodisation should not pay undue attention to the big numbers}

The end of a century undoubtedly exerts certain effects on cultural mentalities, but there is no reason to believe that people suddenly translate differently as soon as the big numbers change. The use of centuries as units of periodisation can only be useful as an arbitrary grid able to reveal processes of more determinate extension. This is the only sense in which the term "nineteenth-century translation" might correspond to a valid unitary entity, and then only as an initial way of approaching a more meaningful historical level.

When images of translation networks are pegged to two-dimensional grids formed by years and cities, they indicate, albeit roughly, their own spatial and temporal extensions. Non-arbitrary periodisation should thus come from the study of translational movements themselves, independently of big numbers and national political regimes. But the task is hazardous and ultimately depends on the nature of the problematic to be addressed, since it is materially impossible to locate and plot all the translations carried out in any modern period, and the texts to be dealt with must thus be pre-selected in terms of the historical hypotheses to be tested.

\section{Translations are not necessarily passive}

Of the three cited arguments, Holmes's is the only one to suggest any significant degree of historical causality. There is, says Holmes, a relation between things like "weak genre concepts" and "mimetic-form translation". Although the exact nature of this relation is far from clear, Holmes generally considers that "weak genre concepts" etc. were the historical conditions of "mimetic form translation", and not vice versa. That is, translators worked in a certain way because certain conditions existed in the target cultures; Holmes does not consider the inverse possibility that nineteenth-century target cultures were as they were because of the way certain translators worked. What matters, for him, is that translations can be explained in terms of their historical context; they are data that can potentially shed light on that context. Similarly, according to Antoine Berman, "la traduction est porteuse d'un savoir sui generis sur les langues, les littératures, les mouvements d'échange et de contact, etc." (1984: 290), a statement closely associated with Goethe's belief that "the relations between an original and a translation are those that most clearly express the relations between nation and nation" (cited ibid: 92). Thus rumoured to "provide knowledge" or to "express relations", 
translations are seen as results for which the historian apparently has to locate explanatory conditions in the contextual languages, literatures or cultures. Yet surely translators work not to express existing relations between cultures but rather to introduce new elements, to change at least one of the cultures and the perception of the other, and thus to alter existing intercultural relations? Surely translations are not just passive expressions of a stable world but also active transfers of knowledge, in themselves partial causes of wider historical changes? But lamentably few researchers seem methodologically inclined to accept that translations actually do anything as intercultural acts.

The prose-effect hypothesis evidently assumes that translations can be active rather than passive. Indeed, it probably errs by attributing excessive social power to translators. But it does not proclaim any mechanistic determinism. If prose translations stood in a causal relationship to prosification, this does not mean that prosification was exclusively the result of prose translations, nor that a series of further factors could not in turn explain why such translations were undertaken. Translations cannot be seen as the sole agents of cultural change. However, unless some degree of causality is admitted, historical research is methodologically unable to distinguish between important and trivial data, between theoretical declarations of intent and actual historical effects, or between arbitrary and substantial periodisations. That is, if translations are assumed to be merely passive expressions of wider factors, they elude all the criteria by which propositions like the prose-effect hypothesis might be tested.

\section{Methodological hypotheses should be falsifiable}

The impressionistic style of the approaches we have so far dealt with is far surpassed by an important study on "Translated Literature in France, 1800-1850", by José Lambert, Lieven D'hulst and Katrin van Bragt (1984). The study analyses a corpus of some 8,000 translations to reach findings that I hope can be summarised as follows:

Between 1820 and 1830 translations were central to the conflict between the classical system of literary conventions and Romantic transgressions of these conventions. In particular, classical verse forms were challenged by new ideas about translation which allowed more extensive use of prose. But prose translations in the highly codified domains of the theatre and of classical texts did not immediately enter the theatre or the canon, thus occupying an intermediary "non-systemic" position that was eventually to support the Romantic system. In poetry, the prosification brought in through translation was replaced after 1830 by the new verse forms of the Romantics. In narrative genres, there were few conventions to challenge and thus a wide diversity of translation strategies. Overall, "we have the translators 
and the authors of prose works to thank for the gradual penetration of ordinary speech into elevated literature". (1984: 162)

This approach avoids most of the shortcomings I have complained about above. It explicitly shuns isolated or anecdotal data ("no translated text is studied on its own", 151); it uses arbitrary periodisation only as a starting point for the location of substantial points of rupture (1830 is the general turning-point revealed by the study of translations themselves); and its conclusions allow that translators played an active role in the process of prosification. I remember first reading this study with genuine excitement. At last someone recognised that nineteenth-century translation was not just literalist! At last someone knew that there was a relation between translation and prosification! But then, did this highly encouraging approach allow me to test the proseeffect hypothesis?

A few carping questions might explain the passing of my enthusiasm.

First, what problem was this corpus designed to address? Although we are told that "the aim of the project was to study the literary function(s) of translations produced and distributed in France in the period from 1800 to 1850" (149), this is not really a hypothesis open to falsification. The attainment of this aim cannot be a finding as such, but a justification of a method: I suspect the mission was to demonstrate how a systembased methodology can be applied or adapted to this particular object. The fact that the study succeeds is admirable, but by what criteria could it have failed? What limitations did its methodological precepts impose and then justify? What kind of data or questions were excluded from consideration?

Why, for example, should the object of study be limited to France? If individual cases are to be rejected in favour of generalities ("no translated text is studied on its own", 151), why should this same principle not be applied to the level of nations? Why should the French literary system be studied on its own? Is it any more or less a system than is an individual translation? What is to stop the anecdotal from simply returning on a higher level? But the selection of a single system is one of the major principles of the methodology employed: "It is the receiving literature that determines the translational method and its function" (150), or so say the researchers from the outset, as if it were a universal axiom. This principle of target-side dominance effectively blocks out intercultural causality and thus, if rigorously applied, should make the prose-effect hypothesis untenable because untestable. Hence my doubts about one-sided system theory.

But I suspect the researchers themselves would find it difficult to maintain such a strict reading of their apparent axiom. Significantly, they appear to have difficulty describing the active or passive role of translations: as cultural expressions of targetside dominance, translations are amorphously "central to the [French] Romantic 
conflict" (152), but as agents of change they can "herald the poetry of the future" (161). Passive and active analytical images are thus found side by side. And yet, it is not clear how target-dominated translations could hope to alter the target system: if everything is already at the receiving end, how can anything change the receiving end? In the final analysis, we find a fundamental confusion of representation and causality shielded by vague references to "non-systemic" positions, which might also be interpreted as a series of positions which cannot be described by system theory, particularly when methodology will not let one look beyond the limits of France. As if writers and translators were similarly bound to look one way and not the other. As if they reacted exclusively to their national past, and not to their multicultural present.

Is it reasonable to expect that the translators involved in the "struggle for Romanticism" necessarily had more to do with aged systemic opponents like Boileau and Delille than with potential models, allies and accomplices like their German and English contemporaries? Why should literary relations be merely diachronic within a national system? Was there no synchronic dimension linking European writers in a wider network of which French literature was merely a part? Were the French somehow free to select from a universal and inexhaustible supply of texts unaffected by sourceculture evaluation? Was there no significant "preselection" by the other Romantic literatures? More importantly, is not a researcher like Jauss at least partly correct when he claims that, thanks largely to synchronic relations, the changes affecting French literature around 1830 were the same as those then taking place in Germany, linked as "zwei gleichzeitige Aspekte einer Epochenwende", two simultaneous aspects of the same historical watershed (1970: 120). And if Jauss's hypothesis is justified - along with his critique of the nationalist categories retained in contemporary literary studies, surely the role of French translators was then intra-systemic, working within the system of European Romanticism, rather than nationalistically systemic or nonsystemic?

Or again, to continue the carping questions, since numerous translations into French were "intermediary translations" for the Iberian world (e.g. many Russian texts were translated from French into Spanish), should the "receiving system" also include Spain, Portugal and Latin America? Or should one apply a different systemic model to each of these latter cases? But the model of target-side dominance, like pure demand economies, becomes dangerously deceptive when dealing with dependent literatures... that is, with virtually all other literatures except those central to Romanticism. The problem here is not so much that one would have to act as if Spanish Americans were sovereign in their own land (even though they often worked and translated in Madrid and Paris); it is that one would therefore have to conclude that they were never the receivers or agents of cultural imperialism. Aware of such potential blindness, system theorists do attempt to explain more than just single systems, tending to lose themselves 
in a plethora of subsystems and megasystems and polysystems and non-systems - rather like the paracultures, diacultures and idiocultures on the fringes of Skopostheorie -, rather than ask if there might be some more adequate or elegant terms based on what translators actually do (interrelate and exchange) and where they actually do it (intercultural frontiers). But let us continue with the questions.

Why limit causality to the literary system? There can be no doubt that literature has its own conventions and that these conventions are closely connected with literary translations. But we have posited that a single literature need not be the sole cause of change in literary translations, and that literary translations need not be the sole cause of change in literary conventions. Given that historical causality passes through a multiplicity of diverse factors, can a history of literary Romanticism and its intercultural dimensions exclude Napoleon and reactions to Napoleon? Can the changes occurring in literature and translation around 1830 be considered in isolation from the July 1830 Revolution? Are the intercultural relations expressed through translations ever entirely without relation to international relations on the political, economic or even military levels? Or must we limit our vision of human history to the mutual adjustments of discrete receptive systems? And a final question:

Why is no significance attached to the prose/verse status of the original texts, nor to their nationality? Although the article mentions that some of the 8,000 translations in the corpus were from writers like Hoffmann, Shakespeare, Milton and Walter Scott, the analysis proceeds as if the directionality and nature of the source texts were without importance. This effectively makes it impossible to assess not only the relative synchronicity or diachronicity of translational relations, but also, since no importance is attached to the form of source texts, the actual work of translators themselves. System analysis of this kind seems uninterested in finding out if change in the prose/verse divide came from the influence of foreign forms or from organically adaptive translational work. It seems not to ask this question because its methodology has already answered it (change is supposed to come from reception). That is, system theory seems uninterested in the basic terms of the prose-effect hypothesis. More belligerently, one could probably argue that although such models very good at describing effects, they are basically inadequate to the concrete causality of change.

As can be seen, most of my doubts about system theory derive from its exclusive focus on the target side. I see this focus as discounting active synchronic relations, reproducing nationalistic presuppositions, overlooking the dynamic of transcultural influences as agents of change, and precluding the analysis of cultural imperialism, as well as turning a blind eye to the prose-effect hypothesis. But the most frustrating thing about the axioms of system theory is that they seem able only to look for what they hope to find, with something of the methodological certitude of a self-fulfilling 
prophecy. Which is why I have tried to test them on the basis of a hypothesis developed from slightly different axioms.

\section{Translators should be distanced from receiving cultures}

Although the principles of system theory broadly identify translators with their receiving culture, it is not unreasonable to suppose that translators constitute a special collectivity in that, if not entirely bicultural (bi-systemic?), they are by definition peculiarly well informed about transcultural relations; they are especially aware of what is happening on the other side of borders; by definition, their decisions are not formulated within the same systemic limitations as those who need to read their translations. For these reasons, translators should be considered distanced from their readers and receiving societies. After all, if this distance did not exist, it is very difficult to see how translations could bring anything new to the receiving system. So how can one seriously maintain that "the receiving literature determines the translational method and its function"?

This unfortunate precept now extends beyond system studies. Let me just note three minor examples.

1. Christiane Nord has recently assumed as axiomatic that "the translator is always acting within the boundaries of a particular culture community" (1991: 93-94). She thus inevitably finds that "translation methods are culture-specific" and believes with equal inevitability that "there will never be a common translation code for all cultures" (92). This is conservative and pessimistic shortsightedness, highly untypical of an otherwise excellent theorist. Translators are not within a culture; they always act on the boundaries of cultures; their work is thus always intercultural; and as for the fatality of a future which it seems translators can never influence (but then, who has the distance necessary to change translation conventions?), Nord's conclusion is like saying that, since there have always been wars there can never be peace, or since a few countries have used different systems for television transmission, television transmission systems are and always will be universally culture-specific. What is actually happening here is that the methodology adopted precludes any possibility of finding translation conventions that are not culture-specific. That is, the methodological premises are not open to falsification by any historical findings. The axioms of target-side dominance thus become sadly self-perpetuating. This would be harmless enough, if only such unfalsifiability did not encourage blindness to translating as an improvable intercultural phenomenon; if only it were not based on a conservative relativism that would take away the promesse de bonheur motivating those of us who think we work and study in order to improve intercultural relations. 
2. Surprisingly similar methods can be found in Susan Bassnett, who makes the following peculiar comment on both Rossetti's 1861 praise of translational servility and Fitzgerald's roughly contemporaneous dictum concerning the translator's superiority over "inferior" foreign poets:

"These two positions, the one establishing a hierarchical relationship in which the SL author acts as a feudal overlord exacting fealty from the translator, the other establishing a hierarchical relationship in which the translator is absolved from all responsibility to the inferior culture of the SL text are both quite consistent with the growth of colonial imperialism in the nineteenth century. From these positions derives the ambiguity with which translations have come to be regarded in the twentieth century." (1980: 4)

Here an apparently axiomatic belief in two centuries of epistemological consistency bisected by big numbers - overlooks the possibility that these translators might have played distinctive roles within and against the dominant colonialist regime. Should translators pretend to be above their authors? According to Bassnett's very concise provocation, colonialist if you do, and colonialist if you don't, since the terms of the debate are colonialist-imperialist even before the translator enters the scene. Verse or prose, conservative or innovative, it makes no essential difference. As if to compensate for system theory's inability to analyse imperialist relations, here we find imperialism elevated to the level of a universal system itself. It is thus methodologically assumed to be the only ideology to have dominated nineteenth-century Europe (but what of nationalism, progress, positivism?); and translation is supposed to have had no active historical effect on it at all. As such, these methodological hypotheses seem even more unfalsifiable than those of system theory, although they do retain the great advantage of raising more questions than they can ever hope to answer.

One such question might be based on Fitzgerald's comment as cited by Bassnett:

"It is an amusement to me to take what liberties I like with these Persians, who, (as I think) are not Poets enough to frighten one from such excursions, and who really do want a little Art to shape them." [Letter to Cowell, 20 March 1857]

The register is indeed imperialist ("frighten", "excursions", "to shape them"). But perhaps this was necessarily so, since Britain was at war with Persia in 1856-1857 and Fitzgerald was thus in the difficult position of presenting the positive values of an enemy culture. The imperialist vocabulary can thus be seen as a partial defence against a possible charge of treason (traduttore traditore usually concerns the betrayal of 
authors, but here it would concern betrayal of the receiving culture). Fitzgerald's language might seem compatible with imperialism, but his position as a translator, finding beauty in an enemy culture, was not. Such translators cannot be identified with their receiving cultures.

3. As a final example let me cite, almost at random, an otherwise entirely innocent phrase in which Armin Paul Frank and Helga Essmann - excellent and very necessary archeologists - discuss how one should analyse translation anthologies:

"Is the anthology designed to promote an interest in the source literature itself or is it intended as an instigation for the target literature, for instance by furnishing qualities that the anthologist perceives to be missing from the target culture?" (1990: 30, italics in the text)

As might be imagined, I quietly rejoice in way these possibilities assume that the translator-anthologist can influence the receiving culture, either by creating interest or by filling in gaps. But what puzzles me is the presentation of these possibilities as an "either/or" situation, harking back to Schleirmacher's distinction between moving the author towards the reader or the reader towards the author. Why should translation problems have to be decided one way or the other? For Schleiermacher, it was a question of nationalist principle: "Just as a man must decide to belong to one country, just so he must adhere to one language, or he will float without any bearings above an unpleasant middle ground" (in Lefevere 1977: 84). For the normative nationalist, translators should move either the author or the reader, but not both at the same time. However, for translation history, recognition of an "unpleasant middle ground" of mutually moving objects is necessary if one is to explain how it is possible for a translator to interest a reader in a foreign culture (because something is perceived as lacking in the receiving culture) and how it is possible to see that something is missing (because there is interest in a foreign culture). In terms of the prose-effect hypothesis, prosification can only result from translation because certain prose forms are perceived as lacking in the receiving culture, and the perception of that lack can only come from an interest in the verse and prose forms of other literatures. Both conditions are necessary if translation is to contribute to historical change. And the only place where both conditions can hold is the maligned middle ground. Thus, in order for the translator to have an effect on the receiving culture, Frank and Essmann's dichotomy should strictly be framed not as "either/or" but as "and/and", or as a question of relative proportions. And in other circumstances, latter-day nationalists should take a closer look at the historical drama of middle grounds, apparently non-systemic positions, and 
intercultural frontiers. Such locations are not always unpleasant: they are the places where translators work.

\section{Complaint concerning the lack of history in translation histories}

The prose-effect hypothesis was not formulated with any specific reference to translation studies; it is a loose strand from my doctoral thesis, for which the disciplinary location was the sociology of literature. I have come to translation history looking for research able to prove or disprove this and several other intuitions. But what I have so far found offers only occasional insight and remains difficult to evaluate in an interdisciplinary context. I have suggested that this situation can be attributed to at least seven shortcomings: (1) archeological accumulation of data that respond to no explicitly formulated problematic, (2) dependence on anecdotal evidence, (3) indiscriminate periodisation, (4) visions of translations as expressions rather than potential agents of historical change, (5) axiomatic privileging of target cultures, (6) the use of unfalsifiable methodological hypotheses, and (7) failure to appreciate the interculturality of the translator's position.

\section{Note}

* A version of first section of this paper was presented to the $\underline{\text { Segundas Jornadas }}$ Nacionales de Historia de la Traducción, Universidad de León, Spain, 1990, under the title of "Complaint concerning the lack of history in translation histories". Versions of the comments on Christiane Nord and Susan Bassnett also appear in Pym (1992).

\section{References}

Berman, Antoine. 1984. L'épreuve de l'étranger. Culture et traduction dans l'Allemagne romantique. Paris: Gallimard. $311 \mathrm{pp}$.

Frank, Armin Paul. ed. 1989. Der lange Schatten kurzer Geschichten. Amerikanische Kurzprosa in deutschen Übersetzung (= Die literarische Übersetzung, 3.) Berlin: Erich Schmidt Verlag. ix + 325 pp.

Frank, Armin Paul and Helga Essmann. 1990. "Translation Anthologies: A Paradigmatic Medium of International Literary Transfer." Amerikastudien/American Studies. Munich. 35:1. 21-34. 
Holmes, James S. 1970. "Forms of Verse Translation and the Translation of Verse Form." The Nature of Translation. Essays on the Theory and Practice of Literary Translation ed. by James S Holmes, 91-105. The Hague/Paris: Mouton.

Jauss, Hans Robert. 1970. Literaturgeschichte als Provokation. Frankfurt a.M.: Suhrkamp. 251 pp.

Humboldt, Wilhelm von. 1836. Über die Verschiedenheit des menschlichen Sprachbaues und ihren Einfluss auf die geistige Entwicklung des Menschengeschlechts. Zweiter Nachdruck (facsimile). Bonn/Hannover/Munich: Dümmlers Verlag, 1968. 511 pp.

Lambert, José, Lieven D'hulst and Katrin van Bragt. 1984. "Translated Literature in France, 1800-1850." The Manipulation of Literature. Studies in Literary Translation ed. by Theo Hermans, 149-163. London/Sydney: Croom Helm.

Lefevere, André. 1977. Translating Literature: The German Tradition from Luther to Rosenzweig. Assen: Van Gorcum. 111 pp.

Meschonnic, Henri. 1973. Pour la poétique II: Epistémologie de l'écriture, Poétique de la traduction. Paris: Gallimard. 457 pp.

Nida, Eugene A. 1964. Toward a Science of Translating with Special Reference to Principles and Procedures involved in Bible Translating. Leiden: E. J. Brill. $x+331$ pp.

Nord, Christiane. 1991. "Scopos, Loyalty, and Translational Conventions." $\underline{\text { Target }}$ (Amsterdam) 3:1. 91-109.

Pym, Anthony. 1988. "Les notions de «réseau» et de «régime» en relations littéraires internationales." L'Internationalité littéraire ed. by Anthony Pym, 5-18. Paris/Barcelona: Noésis.

Pym, Anthony. 1992. Translation and Text Transfer. An Essay on the Principles of Intercultural Communication. Frankfurt-Main/Berlin/Bern/New York/Paris/Vienna: Peter Lang. 228 pp.

Vega Cernuda, M. A. 1989. "Wilhelm von Humboldt, traductor y teórico de la traducción." Fidus Interpres. Actas de las Primeras Jornadas Nacionales de Historia de 
la Traducción ed. by Julio-César Santoyo et al., vol. II. 199-204. León: Universidad de León. 